\title{
PENGARUH MODUL FISIKA BERBASIS SAINS TEKNOLOGI MASYARAKAT UNTUK MENINGKATKAN PRESTASI BELAJAR SISWA
}

\author{
Tofan P. Firmanto ${ }^{1}$, Sarwanto ${ }^{2}$, Sukarmin ${ }^{3}$ \\ ${ }^{1}$ Program Studi Magister Pendidikan Sains FKIP Universitas Sebelas Maret \\ Surakarta, 57216, Indonesia \\ tofanfirmanto@gmail.com \\ ${ }^{2}$ Program Studi Magister Pendidikan Sains FKIP Universitas Sebelas Maret \\ Surakarta, 57216, Indonesia \\ sarwanto@fkip.uns.ac.id \\ ${ }^{3}$ Program Studi Magister Pendidikan Sains FKIP Universitas Sebelas Maret \\ Surakarta, 57216, Indonesia \\ sukarmin67@staff.uns.ac.id
}

\begin{abstract}
Abstrak
Penggunaan modul pembelajaran pada tahap proses pembelajaran akan sangat membantu keefektivan proses pembelajaran dan penyampaian pesan dan materi fisika yang akan disampaiakan. modul juga dapat membantu siswa meningkatkan pemahaman, menyajikan yang menarik, memudahkan penafsiran, dan menambah informasi baru. Tujuan dari penelitian ini adalah untuk mengetahui pengaruh modul fisika berbasis sains teknologi masyarakat terhadap prestasi belajar siswa. Metode yang digunakan dalam penelitian ini adalah metode Eksperimen dengan pretestposttest control (rancangan tes awal-tes akhir kelompok kontrol). Jenis data yang diperoleh merupakan data kuantitatif dalam bentuk skala interval didasarkan pada hasil eksperimen di dalam kelas, hasil eksperimen tersebut berupa hasil belajar mahasiswa dan merupakan hasil dari perhitungan nilai pre-test dan post-test yang dinyatakan dalam Ngain skor. Ngain untuk penilaian kognitif siswa didapat Ngain 0,7, sdangkan untuk penilaian ketrampilan siswa di dapat rata-rata Ngain sebesar 0,35 dan penilaian sikap siswa sebesar 0,38. Dapat disimpulkan bahwa modul fisika berbasis sains teknologi masyarakat dapat meningkatkan prestasi belajar siswa Adanya peningkatan hasil belajar tersebut disebabkan oleh pembelajaran yang menggunakan modul pembelajaran fisika berbasis sains teknologi masyarakat, langkah langkah atau tahapan-tahapan dalam pelaksanaan pembelajarannya telah tersusun dan terlaksana dengan baik.
\end{abstract}

Kata kunci: Modul pembelajaran, sains teknologi masyarakat, prestasi siswa

\section{Pendahuluan}

Fisika adalah ilmu pengetahuan yang mempelajari sifat dan gejala pada benda-benda di alam. Gejala-gejala ini pada mulanya adalah apa yang dialami oleh indra kita, misalnya penglihatan menemukan optika atau cahaya, pendengaran menemukan pelajaran tentang bunyi, dan indra peraba yang dapat merasakan panas. Fisika menjadi ilmu pengetahuan yang mendasar, karena berhubungan dengan perilaku dan struktur benda, khususnya benda mati. Fisika adalah salah satu ilmu pengetahuan alam dasar yang banyak digunakan sebagai dasar bagi ilmu-ilmu yang lain. Fisika mempelajari materi, energi, dan fenomena atau kejadian alam, baik yang bersifat makroskopis (berukuran besar, seperti gerak Bumi mengelilingi Matahari) maupun yang bersifat mikroskopis (berukuran kecil, seperti gerak elektron mengelilingi inti) yang berkaitan dengan perubahan zat atau energi. Sehingga Fisika menjadi 
dasar berbagai pengembangan ilmu dan teknologi.

Karena ilmu fisika sebagai dasar dari teknologi maka salah satu mata pelajaran yang dipelajari di sekolah. Tetapi sebagian besar siswa-siswa SMA mengatakan bahwa fisika sulit, ini dikarenakan pembelajaran fisika sulit diterima oleh siswa. Untuk mengatasi masalah ini maka pemerintah membuat kurikulum yang sesuai, sehingga pembelajaran yang diberikan guru lebih menarik dan bermakna bagi siswa. Kurikulum ini di perkuat dengan UU NO 20 TAHUN 2003 menyebutkan bahwa pendidikan merupakan usaha sadar dan terencana untuk mewujudkan suasana belajar dan proses pembelajaran agar peserta didik secara aktif mengembangkan potensi dirinya untuk memiliki kekuatan spiritual, keagamaan, pengembanggan diri, kepribadian, kecerdasan, akhlak mulia serta ketrampilan yang diperlukan dirinya, masyarakat, bangsa dan Negara. Sasaran pendidikan dalam inpres no 1 tahun 2010 menyebutkan bahwa sasaran bidang pendidikan adalah terwujudnya kurikulum dan metode pembelajaran aktif berdasarkan nilai budaya bangsa untuk membentuk daya saing dan karakter bangsa.

Pembelajaran merupakan proses ilmiah. Karena itu Kurikulum 2013 mengamanatkan esensi pendekatan ilmiah dalam pembelajaran. Pendekatan ilmiah diyakini sebagai titian emas perkembangan dan pengembangan sikap, keterampilan, dan pengetahuan peserta didik. Dalam pendekatan atau proses kerja yang memenuhi kriteria ilmiah, para ilmuwan lebih mengedepankan pelararan induktif (inductive reasoning) ketimbang penalaran deduktif (deductive reasoning). Penalaran deduktif melihat fenomena umum untuk kemudian menarik simpulan yang spesifik. Sebaliknya, penalaran induktif memandang fenomena atau situasi spesifik untuk kemudian menarik simpulan secara keseluruhan. Sejatinya, penalaran induktif menempatkan buktibukti spesifik ke dalam relasi idea yang lebih luas. Metode ilmiah umumnya menempatkan fenomena unik dengan kajian spesifik dan detail untuk kemudian merumuskan simpulan umum.

Metode ilmiah merujuk pada teknik-teknik investigasi atas fenomena atau gejala, memperoleh pengetahuan baru, atau mengoreksi dan memadukan pengetahuan sebelumnya. Untuk dapat disebut ilmiah, Menurut Roestiyah (2001:80) Metode eksperimen adalah suatu cara mengajar, di mana siswa melakukan suatu percobaan tentang sesuatu hal, mengamati prosesnya serta menuliskan hasil percobaannya, kemudian hasil pengamatan itu disampaikan ke kelas dan dievaluasi oleh guru. Penggunaan teknik ini mempunyai tujuan agar siswa mampu mencari dan menemukan sendiri berbagai jawaban atau persoalan-persoalan yang dihadapinya dengan mengadakan percobaan sendiri. Juga siswa dapat terlatih dalam cara berfikir yang ilmiah. Dengan eksperimn siswa menemukan bukti kebenaran dari teori sesuatu yang sedang dipelajarinya.Sehingga siswa dapat memecahkan suatu masalah.

Proses pembelajaran pada Kurikulum 2013 untuk jenjang SMP dan SMA atau yang sederajat dilaksanakan menggunakan pendekatan ilmiah. Proses pembelajaran menyentuh tiga ranah, yaitu sikap, pengetahuan, dan keterampilan. Dalam proses pembelajaran berbasis pendekatan ilmiah, ranah sikap menggamit transformasi substansi atau materi ajar agar peserta didik "tahu mengapa." Ranah keterampilan menggamit transformasi substansi atau materi ajar agar peserta didik "tahu bagaimana". Ranah pengetahuan menggamit transformasi substansi atau materi ajar agar peserta didik "tahu apa". Hasil akhirnya adalah peningkatan dan keseimbangan antara kemampuan untuk 
menjadi manusia yang baik (soft skills) dan manusia yang memiliki kecakapan dan pengetahuan untuk hidup secara layak (hard skills) dari peserta didik yang meliputi aspek kompetensi sikap, keterampilan, dan pengetahuan.

Kurikulum 2013 menekankan pada dimensi pedagogik modern dalam pembelajaran, yaitu menggunakan pendekatan ilmiah. Pendekatan ilmiah (scientific appoach) dalam pembelajaran sebagaimana dimaksud meliputi mengamati, menanya, mencoba, mengolah, menyajikan, menyimpulkan, dan mencipta untuk semua mata pelajaran. Untuk mata pelajaran, materi, atau situasi tertentu, sangat mungkin pendekatan ilmiah ini tidak selalu tepat diaplikasikan secara prosedural. Pada kondisi seperti ini, tentu saja proses pembelajaran harus tetap menerapkan nilai-nilai atau sifat-sifat ilmiah dan menghindari nilai-nilai atau sifat-sifat nonilmiah.

Berdasarkan observasi awal pelajaran fisika merupakan pelajaran yang dianggap sulit bagi siswa, ini bisa dilihat dari prestasi belajar yang rendah. Materi fisika dianggap sulit dipahami oleh siswa dikarenakan siswa kurang menarik dalam pembelajaran fisika dan siswa kurang berkesandan membosankan pada pembelajaran fisika, sehingga diperlukan metode yang tepat untuk pembelajaran fisika. Selain itu penyebab rendahnya prestasi belajar dikarenakan rendahnya kemampuan memecahkan masalah pada siswa, sehingga siswa kurang menyukai dengan soal-soal yang bersifat verbal. Siswa juga rendah untuk mempresentasikan pendapat karena kurangnya percaya diri tentang konsep fisika, untuk itu pembelajaran fisika dengan metode eksperimen sehingga anak bisa mendapatkan konsep fisika dan berani mempresentasikan hasil eksperimen yang didapat. Selain itu di Sekolah tersebut belum menerapkan kurikulum 2013 yang tepat dikarenakan buku tentang materi untuk kurikulum
2013 belum ada. Oleh karena itu diperlukan modul yang sesuai dengan kurikulum 2013 dengan metode eksperimen untuk meningkatkan kemampuan memecahkan masalah. Permendikbud No. 81A Tahun 2013 menerangkan bahwa kurikulum 2013 menganut pandangan dasar bahwa pengetahuan tidak dapat dipindahkan begitu saja dari guru ke siswa. Jadi pola pembelajaran yang berpusat pada siswa tidak sepaham dengan kurikulum 2013 yang mengehendaki siswa untuk mencari sendiri pengetahuan dan guru hanya berfungsi sebagai fasilitator bagi siswa.

Sehingga diperlukan metodemetode pembelajaran yang sesuai dengan kurikulum 2013 yang menuntut siswa aktif dalam mencari pengetahuan dan menanamkan karakter pada siswa. Keterbatasan tersebut menjadi alternative peneliti untuk menerapkan modul pembelajaran berbasis Sains Teknologi Masyarakat (STM), dengan harapan siswa dapat meningkatkan kemampuan memecahkan masalah. Berdasarkan identifikasi masalah, maka rumusan permasalahan adalah bagaimana pengaruh modul fisika berbasis sains teknologi masyarakat terhadap prestasi belajar sisiwa. Tujuan dari penelitian adalah mengetahui pengaruh modul fisika berbasis sains teknologi masyarakat terhadap prestasi belajar siswa.

\section{Metode Penelitian}

Teknik analisis data yang digunakan dalam penelitian ini adalah analisis deskriptif kuantitatif dan kualitatif, yaitu dengan mendeskripsikan dan memaknai data yang bersifat kuantitatif maupun kualitatif. Sebelum dianalisis, dilakukan proses kuantifikasi data dari kuesioner selanjutnya data tersebut dianalisis dengan menggunakan statistik deskriptif.

1. Kriteria Penilaian 
Penentuan kriteria penilaian terhadap media pembelajaran yang telah dikembangkan dilakukan berdasarkan kriteria berdasarkan angket rating scale. Adapun teknik analisis datanya adalah sebagai berikut:

a. Angket yang telah diisi responden, diperiksa kelengkapan jawabannya, kemudian disusun sesuai dengan data responden.

b. Penskoran jawaban setiap pertanyaan dengan memberikan skor sesuai dengan bobot yang telah ditentukan sebelumnya.

c. Pembuatan tabulasi data.

d. Penghitungan persentase dari komponen angket dengan rumus sebagai berikut:

$$
\begin{gathered}
\text { Skor }=\frac{\text { Jumlah total skor penilaian }}{\text { Jumlah skor maksimum }} \\
\times 100 \%
\end{gathered}
$$

e. Dari persentase yang telah diperoleh kemudian ditransformasikan ke dalam tabel supaya pembacaan hasil penelitian menjadi mudah. Untuk menentukan kriteria kualitatif dilakukan dengan cara:

1) Penentuan persentase skor ideal $($ skor maksimum $)=100 \%$,

2) penentuan persentase skor terendah (skor minimum) $=$ $0 \%$,

3) penentuan range 0 sampai 100 $=100$,

4) penentuan interval sesuai dengan skala yang dikehendaki. Menurut Sugiyono (2012: 93) terdapat skala dalam bentuk kata-kata diantaranya sangat baik, baik, tidak baik, sangat tidak baik,

5) penentuan lebar interval dari lima skala sesuai kata-kata kriteria pada langkah 4), = $100 / 4=25$.

Berdasarkan perhitungan langkah (e) di atas, maka range persentase dan kriteria kualitatif dapat ditetapkan sebagaimana Tabel 3.2. Tabel 3.2. Range Persentase dan

\begin{tabular}{ccc}
\hline Interval $(\%)$ & Kriteria & Keterangan \\
\hline $75<$ skor $\leq$ & Sangat Baik & Layak tanpa revisi \\
100 & & \\
$50<$ skor $\leq 75$ & Baik & Layak dengan revisi \\
$25<$ skor $\leq 50$ & Cukup Baik & Kurang layak \\
$0<$ skor $\leq 25$ & Kurang Baik & Tidak layak \\
\hline
\end{tabular}

\section{Kriteria Penilaian}

(Penentuan interval berdasarkan panduan yang diberikan Riduwan, 2010: 88)

Untuk mengetahui kesimpulan hasil analisis angket terhadap modul Fisika berbasis sains teknologi masyarakat, digunakan metode cut off score (skor batas bawah) terhadap hasil presentase penilaian modul Fisika dengan cara sebagai berikut:

Cut off po int $=\frac{\text { Skor maksimum }- \text { Skor minimum }}{2}$

Hasil penilaian yang digunakan adalah hasil validasi oleh ahli pengembangan modul, ahli media, ahli materi, ahli bahasa, guru, dan teman sejawat. Selain untuk analisis penilaian hasil uji dari validator, juga digunakan untuk penilaian hasil keterbacaan dan respon siswa serta hasil respon guru pada saat penyebaran produk modul Fisika. Jika skor rata-rata hasil penilaian kurang dari skor batas bawah, maka dapat disimpulkan bahwa modul Fisika berbasis sains teknologi masyarakat tidak layak untuk digunakan.

2. Analisis Data Tahap Uji Pemakaian

Analisis data tahap uji coba merupakan analisis uji coba modul pembelajaran Fisika yang dikembangkan sebagai berikut:

a. Data Prestasi Belajar 
1) Analisis Perbedaan Hasil Belajar dan Kefektifan Modul Fisika

Untuk menganalialis perbedaan hasil belajar dan efektivitas modul digunakan persamaan gain menurut Hake (1998) sebagai berikut :

$$
\langle g\rangle=\frac{\left\langle S_{\text {posttest }}\right\rangle-\left\langle S_{\text {pretest }}\right\rangle}{\left\langle S_{\max }\right\rangle-\left\langle S_{\text {pretest }}\right\rangle}
$$

Keterangan:

$\langle\mathrm{g}\rangle \quad=\mathrm{N}$-gain score atau nilai peningkatan.

$\left\langle S_{\text {Pr etest }}\right\rangle=$ nilai rata-rata pretest $(\%)$

$\left\langle S_{\text {Posttest }}\right\rangle=$ nilai rata-rata posttest (\%)

$\left\langle S_{\max }\right\rangle=$ nilai maksimum

Keputusan uji:

a) Jika $(<\mathrm{g}>) \geq 0.7$ maka gain dikategorikan tinggi;

b) Jika $0.7>(<\mathrm{g}>) \geq 0.3$ maka gain dikategorikan sedang;

c) Jika $(\langle\mathrm{g}\rangle)<0.3$ maka gain dikategorikan rendah.

Persamaan gain tersebut merupakan indikator keberhasilan penelitian pengembangan perangkat pembelajaran adalah peningkatan perolehan gain hasil analaisis pretest dan posttest sekurang-kurangnya sedang (medium). Ini berarti apabila gain yang diperoleh lebih dari 0,44 maka penelitian pengembangan ini dikatakan terjadi peningkatan. Jika tidak demikian maka penelitian pengembangan ini dikatakan belum terjadi peningkatan hasil belajar siswa. Analisis pengingkatan ini berlaku di setiap kondisi sesuai skor tertinggi yang diperoleh siswa.

b. Analisis Keterampilan dan Sikap siswa

Data keterampilan dan sikap siswa diperoleh melalui observasi di kelas pada setiap proses pembelajaran. Pada setiap proses pembelajaran akan diperoleh hasil rata-rata nilai. Hasil akhir akan dibandingkan peningkatan ratarata setiap proses pembelajaran.

\section{Hasil Penelitian dan Pembahasan}

1) Analisis keterbacaan dan respon siswa

Setelah dilakukan proses pembelajaran menggunakan modul Fisika yang dikembangkan selanjutnya siswa diminta mengisi angket keterbacaan dan respon siswa. Hasil isian keterbacaan dan respon siswa untuk mengetahui kelayakan modul jika digunakan pada kelompok sebanyak 30 siswa. Adapun rangkuman hasil analisis keterbacaan dan respon siswa disajikan pada Tabel 4.1 .

Hasil respon siswa terhadap produk modul Fisika untuk kelas kelompok besar pada Tabel 4.1 menunjukan bahwa skor batas bawah penilaian (Natural Cut off Score) yaitu $75 \%$ sedangkan rata-rata hasil penilaian produk modul Fisika adalah $81.98 \%$ dengan kategori sangat baik, sehingga dapat disimpulkan bahwa produk modul Fisika yang dikembangkan layak digunakan. Hasil analisis keterbacaan dan respon siswa kelompok besar selengkapnya pada Lampiran.

Tabel 4.1 Rangkuman Hasil Analisis Keterbacaan dan Respon Siswa

\begin{tabular}{ll}
\hline Aspek & Persentase (\%) \\
\hline Isi Modul & 82,4 \\
Penyajian & 81,5 \\
Bahasa/Keterbacaan & 82,4 \\
\hline Nilai Maksimum & 96,88 \\
\hline Nilai minimum & 53,13 \\
\hline Nilai Rerata & 81,98 \\
\hline Natural Cut Off Score & 75 \\
\hline
\end{tabular}


2) Analisis penilaian hasil belajar siswa.

Hasil belajar yang berdasarkan dari nilai perbandingan antara pretest dan posttest. Nilai pretest dan posttest diperoleh menggunakan modul Fisika berbasis sains teknologi masyarakat dalam pembelajaran. Hasil rata-rata nilai pretest dan posttest pada Tabel 4.2.

Tabel 4.2 Rangkuman Hasil Analisis Penilaian Hasil Belajar Siswa

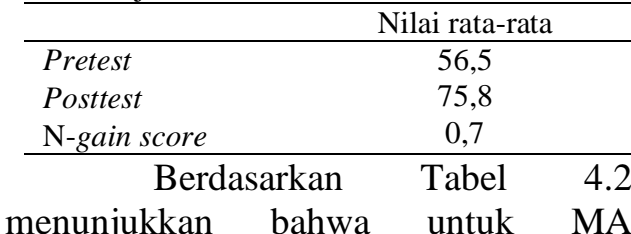

Unggulan Darul Ulum yang proses pembelajarannya menggunakan modul Fisika berbasis sains teknologi masyarakat memiliki N-gain score hasil belajar sebesar 0,7. Analisis data pretest dan posttest terdapat pada Lampiran.

3) Analisis penilaian keterampilan siswa.

Metode yang dipergunakan untuk penilaian keterampilan adalah observasi dilakukan pada kelas yang menggunakan modul Fisika berbasis sains teknologi masyarakat. Data penilaian keterampilan diperoleh dari nilai hasil observasi pada setiap proses kegiatan pembelajaran. Hasil penilaian observasi keterampilan siswa terdapat pada Tabel 4.3. Berdasarkan Tabel 4.3 diketahui bahwa pembelajaran dengan modul Fisika berbasis sains teknologi masyarakat terdapat rata-rata keterampilan siswa. Hasil analisis keterampilan siswa terdapat pada Lampiran.

Tabel 4.3. Rangkuman Hasil Analisis Penilaian Keterampilan Siswa

Grafik Analisis Penilaian Keterampilan Siswa

\begin{tabular}{llcc}
\hline \multicolumn{1}{c}{ Indikator } & \multicolumn{3}{c}{ Nilai rata-rata keterampilan } \\
\cline { 2 - 4 } & Pretest & Postest & $\begin{array}{c}\mathrm{N}- \\
\text { gain }\end{array}$ \\
\hline Mengumpulkan & 3,0 & 3,3 & 0,3 \\
Menganalisis & 2,3 & 3,2 & 0,5 \\
Mempresentasikan & 2,7 & 3,0 & 0,25
\end{tabular}

4)

Analisis penilaian sikap siswa.

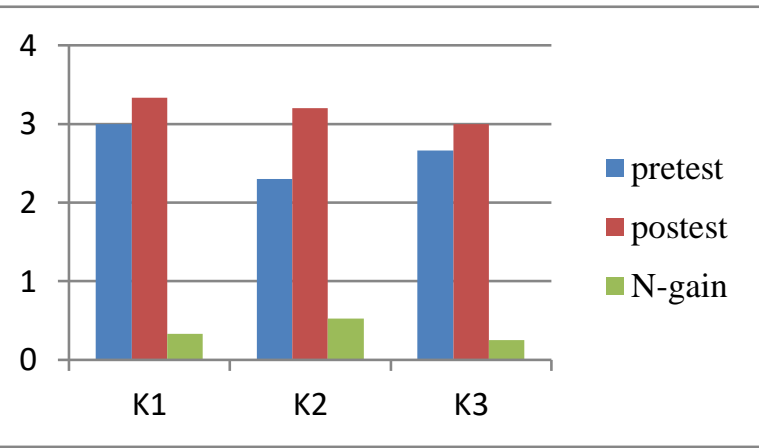

Data penilaian sikap diperoleh dari percobaan yang dilakukan siswa meliputi: Rasa Ingin Tahu, Bekerja sama, Tanggung jawab, Kritis dan Kagum akan kebesaran Tuhan. Hasil skor rata-rata penilaian Sikap tersaji pada Tabel 4.4. Berdasarkan Tabel 4.4. diketahui bahwa proses pembelajaran dengan modul Fisika berbasis sains teknologi masyarakat terdapat rata-rata sikap siswa yang menonjol yaitu pada sikap Rasa ingin tahu, bekerjasama dan kritis. Hasil analisis sikap siswa terdapat pada Lampiran.

Tabel 4.4. Rangkuman Hasil Analisis Penilaian Sikap Siswa

\begin{tabular}{lccc}
\hline & \multicolumn{3}{c}{ Hasil rata-rata nilai sikap } \\
\cline { 2 - 4 } Indikator & Pretest & Postest & N-gain \\
\hline Rasa Ingin Tahu & 2,4 & 3,1 & 0,5 \\
Bekerjasama & 2,6 & 3,4 & 0,5 \\
Tanggungjawab & 2,4 & 3,0 & 0,4 \\
Kritis & 2,2 & 2,7 & 0,3 \\
Kagum akan & & & \\
kebesaran Tuhan & 2,8 & 3,0 & 0,2 \\
\hline
\end{tabular}

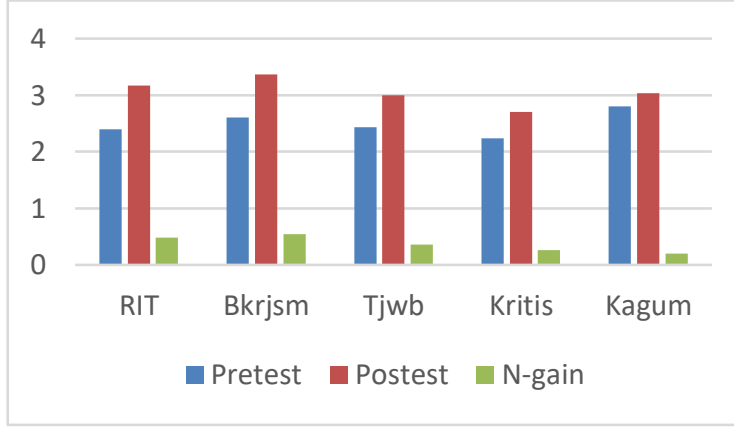

Grafik Penilaian Sikap Siswa 


\section{Kesimpulan dan Rekomendasi}

Dari data yang didapat maka dapat disimpulkan bahwa modul fisika berbasis sains teknologi masyarakat dapat mempengaruhi prestasi belajar siswa. hal ini dapat dilihat dari Ngain untuk penilaian kognitif siswa didapat Ngain 0,7, sdangkan untuk penilaian ketrampilan siswa di dapat rata-rata Ngain sebesar 0,35 dan penilaian sikap siswa sebesar 0,38. sehingga dapat disimpulkan bahwa modul fisika berbasis sains teknologi masyarakat dapat meningkatkan prestasi belajar siswa.

\section{Daftar Pustaka}

Depdiknas. (2003). Standar Penilaian Buku Pelajaran Sains. Jakarta: Pusat Perbukuan.

Poedjiadi,Anna.(2007).Sains Teknologi Masyarakat: Metode Pembelajaran Kontekstual Bermuatan Nilai.Bandung:Remaja Rosda Karya.

Roestiyah,N.K.(2001).Strategi Belajar Mengajar.Jakarta:Rineka Cipta

Trianto. 2007. Model-Model Pembelajaran Inovatif Berorientasi Konstruktivistik. Jakarta: PT Prestasi Pustaka.

Slameto. (2012). Belajar dan Faktor yang Mempengaruhinya. Jakarta: PT Rineka Cipta. 